\title{
Investigation of The Effect of Smoking on Some Blood Parameters and Respiratory Functions in Wrestlers
}

\author{
Kürşat HAZAR ${ }^{1}$ \\ ${ }^{1}$ Muğla Sttkı Koçman Universty, Department of Physical Education and Sports, Muğla, Turkey \\ Address Correspondence to Kürşat Hazar, e-mail: kursathazar@hotmail.com
}

\begin{abstract}
This study was conducted to investigate the effects of smoking on some blood parameters and respiratory functions in wrestlers. To the study 18 non-smoker wrestling athletes for at least 11,500 years, studying at different departments at Muğla S1tk1 Koçman University Faculty of Sport Sciences, whose average age 20,888, average height 177,555, average weight 82,777 kg; and 16 athletes smoking 15, 062 pieces of cigarettes in a day for averagely 3, 406 years, doing licenced wrestling at least for 11,625 years whose average age 22, 000, height average 179,375, weight average 86, 250; a total of 34 male individuals voluntarily participated in the study. Height and body weight measurements, blood analysis and pulmonary function tests were respectively applied to the participants. Statistical analysis of the obtained data was done by SPSS 21.00 package program. Since the data were distributed normally, the Independent-Samples T Test was used for intergroup comparisons, and the level of significance was set at $p<0.05$ and 0.01 by using regression analysis test methods. RBC values of the smokers were significantly higher than the ones who did not $(\mathrm{p}<0.01)$, and the results of the respiratory function test showed that there were significant differences in favor of the non-smokers $(p<0.01, p<0.05)$. While RBC and HGB values of cigarette users were found to be significantly higher, non-smokers had a $35,2 \%$ effect on RBC values of 33,9\%, while FVC and FEF25 / 75 were significantly lower than non-smokers. FVC values of $-47,4 \%$, and FEF25 / 75 were found to have an effect of $-65,7 \%$. In conclusion, it was determined that smoking in wrestlers has statistically significant but negative effects on some blood parameters and respiratory functions. For this reason, it is necessary to emphasize the importance of smoking in the wrestlers to ensure that both athletes and coaches demonstrate the required sensitivity.
\end{abstract}

Key words:Wrestling, smoking, blood parameters, respiratory functions

\section{INTRODUCTION \& AIM}

Wrestling is defined as the struggle of two athletes to make each other superior by using their techniques, skills, forces, and intelligence in accordance with the rules determined by World Wrestling Association without using a vehicle on a custom-made canvas cushion with dimensions $(24,27)$. Wrestling is a challenging sport with short periods and a resting element, which requires highintensity effort and includes submaximal and maximal loads with the athlete's physical superiority (17). Also; Wrestling is also defined as a sports branch where anaerobic energy metabolism is used predominantly, affecting the performance of motor factors such as force, speed, quickness, balance, flexibility, muscular and cardiovascular endurance and coordination $(8,3)$.

The fact that smoking is easy to obtain and the use of it is legal, which makes individuals addicted, it is considered to be valid for athletes (26). In a study, $14.1 \%$ of northern American aboriginal athletes $(\mathrm{n}=156$; mean age: $19.6 \pm 7.4)$ were reported to smoke regularly.33 However, there are some studies showing that male athletes use cigarettes more commonly in the season break than in the season (35).

Smoking is an important risk factor for many lethal diseases, including chronic lung cancer. It can cause diseases such as respiratory diseases, cardiovascular diseases, type 2 diabetes, and hypertension. Research shows that smoking increases the risk of coronary heart disease by 2 to 4 times. Smoking can cause lung diseases, emphysema, and chronic bronchitis. Smoking opens a new door into diseases such as blood (acute myeloid leukemia), cervix, colon and rectum, and esophageal cancer (30). 
During exercise, at the end of the interaction among respiratory ventilation, cardiac output, systemic and pulmonary blood flow, the metabolic needs of skeletal muscles should be met. The metabolic rate of the muscle increases 50 times, especially during heavy exercise (31). While a significant change in breathing volume and frequency occur during exercise; $\mathrm{O} 2$ consumption rate increases in maximal aerobic metabolism (28). The increase in the need for energy due to the work done results in the production of a significant number of metabolic by-products at the end of the accelerated muscle metabolism. One of these products is the reactive oxygen species, also known as free radicals formed by different biological mechanisms in the body (23).

While the maximal oxygen consumption corresponding to the effort during exercise is considered to be important in terms of performance, the physical and physiological characteristics of the wrestlers are important in terms of performance improvement and performance control (3). This research was carried out to investigate the effects of smoking on some blood parameters and respiratory functions in wrestlers.

\section{METHOD}

Into the study, Participants: To the study, 18 non-smoker wrestling athletes for at least $11 \pm 500$ years, studying at different departments at Muğla Sıtkı Koçman University Faculty of Sport Sciences, whose average age $20 \pm 888$, average height $177 \pm 555$, average weight $82 \pm 777 \mathrm{~kg}$; and 16 athletes smoking $15 \pm 062$ pieces of cigarettes in a day for averagely $3 \pm$ 406 years, doing licensed wrestling at least for $11 \pm$ 625 years whose average age $22 \pm 000$, height average $179 \pm 375$, weight average $86 \pm 250$; a total of 34 male individuals voluntarily participated in the study. Participants were informed about the study and signed an attendance form regarding that they were voluntary.

\section{Data Collection Methods}

The participants were subjected to height and body weight measurements, blood analysis and pulmonary function tests, respectively.

\section{Measurements of Height and Body}

The height measurements of the participants were measured with Holtain Limited brand size meter with a precision of $0.01 \mathrm{~cm}$ and body weights were measured with an Angel brand electronic scale with a precision of $0,1 \mathrm{~kg}$.

\section{Blood analyses}

Blood samples of the participants were taken by a specialist in a private hospital and analyzed in the laboratory of the same hospital. White blood cells (WBC), red blood cells (RBC), hemoglobin levels (HGB), hematocrit (HCT), platelet (PLT), LDL cholesterol (LDL), HDL cholesterol (HDL) and triglyceride values were analyzed.

\section{Pulmonary Function Tests}

Pulmonary function tests were performed with MEC Pocket-Spiro USB100 spirometer. The participants were informed about the measurement rules before the test and the measurements were recorded three times and the highest values were recorded. orced Expiratory Volume (FEV1) in one second from respiratory parameters, forced vital capacity (FVC), peak expiratory flow (PEF), forced expiratory center flow rate (FEF 25/75), and forced expiratory volume per second to forced vital capacity (FEV1 / FVC) were used.

\section{Data Analysis}

The statistical analyses of the obtained data were done in SPSS 21.00 package program on a personal computer. In the data showing normal distribution, intergroup comparisons were made by Independent-Samples $\mathrm{T}$ Test and regression analysis was used to determine the effect of variables. 


\section{FINDINGS}

Table.1: Descriptive Statistics of the Participants

\begin{tabular}{lllcccc}
\hline & Variables & $\mathrm{N}$ & Minimum & Maximum & $\overline{\mathrm{X}}$ & Std. D. \\
\hline \multirow{5}{*}{ Non Smoker } & Age & 18 & 18.00 & 22,00 & 20,88 & 1.231 \\
\cline { 2 - 7 } & Height & 18 & 168.00 & 186.00 & 177.55 & 6.491 \\
\cline { 2 - 7 } & Weight & 18 & 66.00 & 93.00 & 82.77 & 8.795 \\
\cline { 2 - 7 } Smokers & Sporting Year & 18 & 9.00 & 15.00 & 11.50 & 1.723 \\
\hline & Age & 16 & 20.00 & 25.00 & 22.00 & 1.932 \\
\cline { 2 - 7 } & Height & 16 & 170.00 & 188.00 & 179.37 & 6.042 \\
\cline { 2 - 7 } & Weight & 16 & 72.00 & 109.00 & 86.25 & 12.635 \\
\cline { 2 - 7 } & Sporting Year & 16 & 9.00 & 15.00 & 11.62 & 1.707 \\
\cline { 2 - 7 } & Smoking Duration & 16 & 1.00 & 6.00 & 3.40 & 1.331 \\
\cline { 2 - 7 } & Pieces in a day & 16 & 10.00 & 20.00 & 15.06 & 4.057 \\
\hline
\end{tabular}

\begin{tabular}{|c|c|c|c|c|c|c|}
\hline Variables & & $\mathrm{N}$ & $\overline{\mathrm{X}}$ & Std. D. & $\mathrm{t}$ & $\mathrm{p}$ \\
\hline \multirow[t]{2}{*}{ WBC $10^{*} 3 / \mathrm{u} \mathrm{L}$} & Non-Smokers & 18 & 7.82 & 1.595 & .216 & .830 \\
\hline & Smokers & 16 & 7.71 & 1.290 & & \\
\hline \multirow[t]{2}{*}{ RBC $10^{*} 6 / \mathrm{u} \mathrm{L}$} & Non-Smokers & 18 & 5.25 & .122 & -3.771 & $.001^{* *}$ \\
\hline & Smokers & 16 & 5.76 & .564 & & \\
\hline \multirow[t]{2}{*}{ HGB g/d L } & Non-Smokers & 18 & 15.54 & .675 & -.835 & .410 \\
\hline & Smokers & 16 & 15.78 & 1.007 & & \\
\hline \multirow[t]{2}{*}{ НCT \% } & Non-Smokers & 18 & 47.06 & 3.091 & -.134 & .894 \\
\hline & Smokers & 16 & 47.19 & 2.623 & & \\
\hline \multirow[t]{2}{*}{ PLT $10^{*} / \mathrm{u} \mathrm{L}$} & Non-Smokers & 18 & 264.11 & 44.880 & -.220 & .827 \\
\hline & Smokers & 16 & 267.87 & 54.865 & & \\
\hline \multirow[t]{2}{*}{ LDL mg/dl } & Non-Smokers & 18 & 94.79 & 11.506 & -1.511 & .141 \\
\hline & Smokers & 16 & 102.94 & 19.371 & & \\
\hline \multirow[t]{2}{*}{$\mathrm{HDL} \mathrm{mg} / \mathrm{dl}$} & Non-Smokers & 18 & 43.38 & 8.982 & .704 & .486 \\
\hline & Smokers & 16 & 41.57 & 5.351 & & \\
\hline \multirow[t]{2}{*}{ TRIGLYCERIDE mg/dl } & Non-Smokers & 18 & 116.11 & 22.671 & -1.930 & .063 \\
\hline & Smokers & 16 & 130.09 & 19.094 & & \\
\hline
\end{tabular}

There was a significant difference between the mean values of erythrocyte parameters of the participants $(p<0.01)$. RBC values of non-smokers are higher than the non-smokers.

\begin{tabular}{|c|c|c|c|c|c|c|}
\hline \multicolumn{2}{|l|}{ Variables } & $\mathrm{N}$ & $\overline{\bar{x}}$ & Std. D. & $t$ & $\mathrm{p}$ \\
\hline \multirow[t]{2}{*}{ FEV1 (L) } & Non-Smokers & 18 & 4.99 & .663 & \multirow[t]{2}{*}{3.608} & \multirow[t]{2}{*}{$.001^{* *}$} \\
\hline & Smokers & 16 & 4.28 & .485 & & \\
\hline \multirow[t]{2}{*}{ FVC (L) } & Non-Smokers & 18 & 5.27 & .654 & \multirow[t]{2}{*}{2.782} & \multirow[t]{2}{*}{$.009^{*}$} \\
\hline & Smokers & 16 & 4.68 & .610 & & \\
\hline \multirow[t]{2}{*}{ PEF (L/sn.) } & Non-Smokers & 18 & 8.96 & .464 & \multirow[t]{2}{*}{2.341} & \multirow[t]{2}{*}{$.026^{*}$} \\
\hline & Smokers & 16 & 8.46 & .778 & & \\
\hline \multirow[t]{2}{*}{ FEF25/75 (L/sn.) } & Non-Smokers & 18 & 129.00 & 14.840 & \multirow[t]{2}{*}{5.806} & \multirow[t]{2}{*}{$.000^{* *}$} \\
\hline & Smokers & 16 & 103.75 & 10.700 & & \\
\hline \multirow[t]{2}{*}{ FEV1/FVC \% } & Non-Smokers & 18 & 97.55 & 5.679 & \multirow[t]{2}{*}{.271} & \multirow[t]{2}{*}{.788} \\
\hline & Smokers & 16 & 97.00 & 6.271 & & \\
\hline
\end{tabular}


There were significant differences between the mean values of the respiratory function of non-smokers and smoker participants $(p<0.01$. $p<0.05)$. The average of FEV1. FVC. PEF and FEF 25/75 values of non-smokers were higher than the smokers. There was no significant difference between the FEV1 / FVC values of the participants ( $p>0.05)$.

Table: 4. Regression analysis of the effects of smoking on blood parameters and respiratory function in participants

\begin{tabular}{cccccc}
\hline Model & $\mathrm{R}$ & $\mathrm{R}^{2}$ & SurplusR $^{2}$ & Estimated Standart Error & Durbin-Watson \\
\hline 1 & $.935^{\mathrm{a}}$ & .874 & .802 & .22554 & 1.699 \\
\hline
\end{tabular}

Independent Variable: Smoke

Dependent Variable: RBC. HGB. HCT. HDL. LDL. PCT. TRIGLYCERIDE. FEV1. FVC. PEF. FEF2575. FEV1FVC

The effect of smoking on blood and respiratory function values of the participants was $87.4 \%$.

Table: 5. ANOVA Statistics about Variables

\begin{tabular}{|c|c|c|c|c|c|}
\hline Model 1 & Sum $^{2}$ & Std. D. & Average $^{2}$ & $\mathrm{~F}$ & $\mathrm{p}$ \\
\hline Regression & 7.402 & 12 & .617 & \multirow{3}{*}{12.126} & \multirow{3}{*}{$.000^{\mathrm{b}}$} \\
\hline Surplus & 1.068 & 21 & .051 & & \\
\hline Total & 8.471 & 33 & & & \\
\hline
\end{tabular}

Independent Variable: Smoke

Dependent Variable: RBC. HGB. HCT. HDL. LDL. PCT. TRIGLYCERIDE. FEV1. FVC. PEF. FEF2575. FEV1FVC

There was a significant difference between the mean values of blood and respiratory function according to the smoking status of the participants $(\mathrm{p}<0.01)$.

\begin{tabular}{|c|c|c|c|c|c|}
\hline \multicolumn{6}{|c|}{ Coefficients $^{a}$} \\
\hline \multirow[t]{3}{*}{ Model } & \multirow{2}{*}{\multicolumn{2}{|c|}{ Non-Standart Coefficient }} & \multirow{2}{*}{$\begin{array}{l}\text { Standart } \\
\text { Coefficient }\end{array}$} & \multirow{3}{*}{$\mathrm{T}$} & \multirow{3}{*}{$\mathrm{p}$} \\
\hline & & & & & \\
\hline & B & Std. D. & Beta & & \\
\hline \multirow[t]{2}{*}{ DependentVariabl } & -2.171 & 2.039 & & -1.065 & .299 \\
\hline & & & & & \\
\hline RBC & .833 & .265 & .339 & 3.141 & .005 \\
\hline HGB & .211 & .068 & .352 & 3.132 & .005 \\
\hline HCT & -.017 & .018 & -.095 & -.931 & .362 \\
\hline HDL & .012 & .008 & .182 & 1.464 & .158 \\
\hline LDL & .002 & .004 & .075 & .609 & .549 \\
\hline PCT & .473 & 1.147 & .048 & .413 & .684 \\
\hline TRIGLYCERIDE & .001 & .003 & .063 & .513 & .613 \\
\hline FEV1 & -.024 & .124 & -.032 & -.195 & .847 \\
\hline FVC & -.356 & .102 & -.474 & -3.495 & .002 \\
\hline PEF & .139 & .130 & .179 & 1.070 & .297 \\
\hline FEF2575 & -.019 & .003 & -.657 & -5.613 & .000 \\
\hline FEV1FVC & -.016 & .009 & -.173 & -1.790 & .088 \\
\hline
\end{tabular}

Smoking has a $33.9 \%$ effect on the RBC values on the participants. $\mathrm{RBC}$ values of smokers are higher than those who do not. Smoking has a $35.2 \%$ effect on HGB values. RBC values of smokers are higher than those who do not. Smoking has a $35.2 \%$ effect on HGB values. HGB values of smokers are higher than those who do not. Smoking has a $-47.4 \%$ effect on FVC values. FVC values of smokers are lower than those who do not. Smoking has an effect of $65.7 \%$ on FEF 25 / 75 values. FEF25 / 75 values of smokers are lower than those who do not. 


\section{DISCUSSION AND RESULT}

In this study. which was conducted in order to investigate the effect of smoking on the blood parameters and respiratory function of the wrestlers. a statistically significant difference was found between the groups in terms of blood mean values ( $p<0.01$ ). RBC values of non-smokers were significantly higher than those who did not. In addition. HGB. HCT. PLT. LDL and triglyceride values of smokers were higher than non-smokers. while non-smokers had higher WBC and HDL values.

While studies have shown that chronic smoking causes an increase in platelet activation (11). MPV levels of smokers were significantly higher than non-smokers (20). In a study on Taekwondo athletes. it was reported that there was no statistically significant difference between the platelet. leukocyte. hematocrit and hemoglobin parameters in which the blood samples were evaluated before and after the camp (7). Asif Mohammad et al. investigated the effect of cigarette smoking on hematological parameters in 33-year-old Pakistani smokers and non-smokers. The study found that WBC. RBC. HGB and HCT values were higher in smokers than in non-smokers (4). Mashiko et al stated that no significant difference was seen in the study that they researched 20-day camp's effect on hematological parameters (22). In a study about increased red blood cell distribution range in healthy smoker individuals. Kurtoğlu et al. found that smoking has an important effect on an increase in HGB. HCT and RBC values (19.22). Ghezzi et al. Reported that smoking had a negative effect on lipid levels. and free radicals in cigarette changed lipid synthesis in lipid metabolism by targeting fatty acids (14).

The higher RBC values in smokers may be due to carbon monoxide present in cigarette smoke. Carbon monoxide is associated with $\mathrm{Hb}$ in red blood cells and leads to carboxyhemoglobin. Carboxyhemoglobin affects the oxygen level in the tissue catalyzing the bone and the bone marrow is activated to produce more red blood cells (25). In another study. it was reported that HCT and HB levels were higher in smokers. but this could compensate for the need for oxygen (2).

In this study. although there was a significant difference in the RBC values of the participants. the increase in the HGB values in favor of smokers being statistically significant can be explained with the number of the participants. LDL and TRIGLYCERIDE values of smokers were higher than the non-smokers (13). When the findings are compared with the literature findings; Although there were some opposing views. there was a statistically significant difference only between the RBC and non-smoker participants $(\mathrm{p}<0.05)$; There was no statistically significant difference between WBC HGB. HCT. PLT. LDL. HDL and TRIGLYCERIDE values ( $p>0.05)$. In this respect. the findings obtained from the study largely overlap with the literature findings.

Significant differences were found between the groups with respect to respiratory function values ( $\mathrm{p}$ $<0.01$. $\mathrm{p}<0.05$ ). FEV1. FVC. PEF and FEF 25/75 values of non-smokers are higher than those of the smokers (18). It was seen that there was no significant difference between the FEV1 / FVC values of the participants ( $p>0.05)$.

In a study on non-smokers and non-smokers. FEV1. FVC. PEF and FEF25 / 75 levels of the smokers were significantly lower than the nonsmokers (10). As a result of similar pulmonary function tests. it was found that smokers had lower respiratory functions than those who did not (34.21). In a study conducted on university students. while a significant decrease was observed in FEV1 and FEF 25/75 compared to non-smokers; smoking was found to cause mid-expiratory obstruction in young people (16).

Long-term smoking causes some physiological functions in the respiratory system (29). It causes oxidative damage in the lungs and other tissues through free radicals that are produced by the direct effect of radicals in cigarette smoke or by the production of macrophages and other leukocytes (9). The increased free radicals as a result of smoking cause a decrease in lung volumes and capacities in later periods (36). However. the relationship between smoking and respiratory diseases has been demonstrated by several epidemiological studies worldwide.32 Smoking for along term has caused many physiological conditions such as impaired lung volumes and capacities and cancer (6).

In this study. while it was observed that the pulmonary function values of the smokers were lower than those who did not $(p<0.01 . p<0.05)$. according to the results of pulmonary function tests applied to the participants. it was found that the lung volume and capacities of the cigarette smokers were lower than the non-smokers. 
When the effects of smoking on the blood parameters and respiratory function were examined. it was found that there was a significant difference between the average values of blood and respiration according to the smoking status $(p<0.01)$. In the regression analysis. the RBC and HGB values of the smokers were found to be significantly higher. while the smoking status was found to have an effect of $35.2 \%$ on the RBC values of $33.9 \%$. In addition. while the FVC and FEF25 / 75 values of the smokers were found to be significantly lower than those of the non-smokers. the smoking rate was found to have an $-47.4 \%$ effect on for FVC and $-65.7 \%$ for FEF25 / 75.

Carbon monoxide. one of the active substances found in cigarettes. replaces oxygen with hemoglobin and prevents the blood from carrying oxygen and leads to hypoxia in the tissues. 5Therefore. while there is a significant change in the volume and frequency of respiration during the exercise. it causes a rate in oxygen consumption (28). Sufficient hemoglobin is needed to maintain the maximal oxygen level equaled to effort in exercise. and respiratory insufficiency is among the conditions that elevate critical hemoglobin value (12). It may be considered that sporting performance will decrease due to the negativity caused by smoking in lung volume and capacities. In addition. increased HCT value due to RBC increase leads to increased blood volume while increasing the workload and on the athlete's heart in the same type of exercise. In this sense. performance loss is inevitable in the athlete.

In conclusion. it was determined that smoking in wrestlers has statistically significant but negative effects on some blood parameters and respiratory functions. For this reason. it is necessary to emphasize the importance of smoking in the wrestlers to ensure that both athletes and coaches demonstrate the required sensitivity.

\section{REFERENCES}

1. Abel GA. Hays JT. Decker PA. Croghan GA. Kuter DJ. et al. Effects of biochemically confirmed smoking cessation on White blood cell count. Mayo Clin Proc 2005; 80(8):10221028.

2. Ahmed. O. A. (2017). Effect of Pack-Year of Cigarette Smoking on Erythrocyte Parameters and Glucose Level Among Healthy Males. Gazi Medical Journal. 28(3).

3. Alpay B. HAZAR S. Türk güreş milli takımı sporcularının bazı solunum ve dolaşım parametrelerininNiğde üniversitesi güreş takımı sporcularılla mukayesesi ve değerlendirilmesi. 2006. Atatürk Üniversitesi Beden Eğitimi ve Spor bilimleri dergisi. cilt 8.sayı 3. S: 25-33

4. Asif. $\mathrm{m}$ ve ark. Effect of cigarette smoking based on hematological parameters: comparison between male smokers and nonsmokers. turkish journal of biochemistry turk j biochem] 2013; 38 (1) ; 75-80

5. Başgül A. Sessiz Ölüm: Akut karbon monoksit Zehirlenmesi. Toksikoloji Dergisi. 2004; 2(3):37-43.

6. Clotet J. Gomez-Arbones X. Ciria C. Spirometry is a good method for detecting and monitoring chronic obstructive pulmonary disease in high-risk smokers in primary healthcare. Arch Bronconeumol. 2004;40.155-9.

7. Çakmakçı. E.ErkekTekwondocularda kamp döneminin bazı hematolojik Parametreler Üzerine etkileri. Niğde Üniversitesi Beden Eğitimi ve Spor Bilimleri Dergisi. Cilt 3. Sayı 1. 2009.

8. Çamkerten. D. (2016). Elit güreşcilerde su ilavesinin bazı hematolojik parametrelere etkisi (Doctoral dissertation. Selçuk Üniversitesi Sağllk Bilimleri Enstitüsü).

9. Demir H. Tütün ve sigara içenlerde serum tiyosiyanat seviyeleri ile selenyum. C vitamini ve lipit peroksidasyonu seviyelerinin araştırılması. Yüksek lisans Tezi. Sağ. Bil. Enstitüsü. Şanlıurfa. 1998

10. Demirbaş. N.. \& Kutlu. R. (2018). Sigaranın akciğer yaşı ve solunum fonksiyon testleri üzerine olan etkisi. Cukurova Medical Journal. 43(1). 155-163.

11. Erhardt L. Cigarette smoking: an undertreated risk factor for cardiovascular disease. Atherosclerosis 2009;205.23-32.

12. Fakhry SM. Fata P. Crit Care. How low is too low? Cardiac risks with anemia. Crit Care 2004;8(Suppl 2): S11-4.

13. Fizyolojik Profili. Spor Hekimliği Dergisi. 1984; 19(3): 119130.

14. Ghezzi S. Risé P. Ceruti S. Galli C. Effects of cigarette smoke on cell viability. linoleic acid metabolism and cholesterol synthesis. in THP-1 cells. Lipids 2007;42: 629-36

15. Gitte RN. Effect of cigarette smoking on plasma fibrinogen andplatelet count. Asian Journal of Medical Sciences 2011; 2.181-184.

16. Gold DR. Wang X. Wypij D. et al effects of cigarette smoking on lung function in adolest cent boys and girls. $\mathrm{N}$ engl J med. 335 (13). $931-7.1996$

17. Gökdemir K. Güreş Antrenmanının Bilimsel Temelleri. Poyraz Ofset. Ankara. 2000. s. 15

18. Kandeydi. H. Ergen. E.. “BESYO Öğrencileri ile Tip öğrencilerinin Fizyolojik ve Fonksiyonel özelliklerinin Karşılaştırılması" Spor Hek. Der. 17 (2). 53-59. 1982

19. Kurtoğlu E. Aktürk E. Korkmaz H. Sincer I. Yılmaz M. Erdem K. et al. Elevated red blood cell distribution width in healthy smokers. Turk Kardiyol Dern Ars 2013; 41: 199-206. [CrossRef]

20. Kutlu. R.. \& Demirbaş. N. (2017). Sigaranın Trombosit Sayıs1. OrtalamaTrombosit Hacmi ve Kardiyovasküler Risk Faktörleri Üzerine Etkileri: Bir Olgu Kontrol Çalışması. Medical Bulletin of Haseki/Haseki Tip Bulteni. 55(4).

21. Marcy T. Dorwaldt A. Pinckney R. DeSarno M. Solomon L et al. Motivating smokers in the hospital pulmonary function laboratory to quit smoking by use of the lung age concept. Nicotine Tob Res. 2011;13.1161-6.

22. Mashiko T. Umeda T. Nakaji S. Sugawara K. et all. Effect of Exercise on The Physical Condition of College Rugby Players 
During Summer TrainingCamp Br J Sports Med. 2004; 38: 186 $-190$

23. Özçelik O. Karataş F. Şiddeti Düzenli Olarak Artan İşe Karşı Yapilan Egzersizin Obezlerde Serum Malondialdehid ve Vitamin A. E. C Düzeyleri Üzerine Olan Etkisi. F.Ü. Sağ. Bil. Derg. 2008: 22(6): 337-41

24. Recep Kürkçü. Adnan Ersoy A. Latif Aydos. Güreşçilere Uygulanan 12 Haftalık antrenman Programının Bazı Fiziksel ve Fizyolojik Özellikler Üzerine Etkisi. e-journal of New World Sciences Academy Sports Sciences. 4. s:4. 2009

25. Roethig HJ. Koval T. Muhammad Kah R. Jin Y. Mendes P. Unverdorben. M. Short term effects of reduced exposure to cigarette smoke on white blood cells. platelets and red blood cells in adult cigarette smokers. Regul Toxicol Pharmacol 2010; 57: 333-7.

26. Sagone A. Lawrence T ve Balcerzak SP: Effect of Smoking on Tissue Oxygen Supply. Blood 1973. 41.845-851

27. Savranbaşı. R. Elit erkek serbest güreşçilerde kan laktat düzeyi. kalp atım hızı ve teknikperformans arasındaki ilişkinin incelenmesi. spor hekimliği dergisi. 2011.Cilt 46. Say1 3.sayfa: 087-096

28. Tamer. K. (1995) Çeşitli koşu programlarının aerobik. anaerobik güç ve akciğer fonksiyonlarına etkileriyle ilişki düzeylerinin belirlenmesi. Performans Dergisi. Cilt I Sayı 3. 32-39.

29. Türkoğlu A. baydaş G. Özgüner MF. Altın 1şık M. Arslan. Elazı ̆̆ çimento fabrikaları işçilerinde çimento tozunun akciğer fonksiyonları. kan hematokrit ve hemoglobin değerlerine olan etkisinin araştırılması. Furat ünv. Sağlık bilimleri dergisi 11 (1) : 121-8. 1997

30. U.S. Department of Health and Human Services. The Health Consequences of Smoking 50 Years of Progress: A Report of the Surgeon General. Atlanta: U.S. Department of Health and Human Services. Centers for Disease Control and Prevention. National Center for Chronic Disease Prevention and Health Promotion. Office on Smoking and Health. 2014.

31. Wasserman K. Hansen JE. Sue DY. et al. Physiology of exercise. Principles of ExerciseTesting and Interpretation: Including Pathophysiology and Clinical Applications. 5th ed. Wolters Kluwer Lippincott Williams \& Wilkins. 2011.

32. WHO Report on the Global Tobacco Epidemic 2011: Warning about the dangers of tobacco. http://www.who.int/tobacco/global_report/2011/e n/ Erişim tarihi: 10.05.2017

33. Yakiwchuk CA. Stasiuk H. Wiltshire W. et al. Tobacco use among young North American Aboriginal athletes. J Can Dent Assoc 2005; 71(6):403.

34. Yamaguchi K. A new method for evaluating lung age. Japan Resp Soc. 2011; 49.713-6

35. Yusko DA. Buckman JF. White HR. et al. Alcohol. tobacco. illicit drugs. and performance enhancers: A comparison of use by college student athletes and nonathelets. J Am Coll Health 2008; 57 (3): 281-290.

36. Zerin M. Karakılçık AZ. Cebeci B. ve ark. Üniversite öğrencilerinde kısa ve uzun süre sigara içiminin bazı solunum parametreleri üzerine etkisi. Gaziantep Tip Derg 2010; 16.9-12. 